\title{
Morphological aspects of the ovaries of turtle Kinosternon scorpioides raised in captivity ${ }^{1}$
}

\begin{abstract}
Elba P. Chaves ${ }^{2}$, Sâmia C.R. Oliveira ${ }^{3}$, Lianne P.F. Araújo ${ }^{4}$, Antonia S. Oliveira ${ }^{5}$, Maria A. Miglino ${ }^{6}$, Ana Lúcia Abreu-Silva ${ }^{7}$, Ferdinan A. Melo ${ }^{7}$ and Alana L. Sousa ${ }^{8 *}$

ABSTRACT.- Chaves E.P., Oliveira S.C.R., Araújo L.P.F., Oliveira A.S., Miglino M.A., Abreu-Silva A.L., Melo F.A. \& Sousa A.L. 2012. Morphological aspects of the ovaries of turtle Kinosternon scorpioides raised in captivity. Pesquisa Veterinária Brasileira 32(7):667671. Departamento das Clínicas, Curso de Medicina Veterinária, Universidade Estadual do Maranhão, Cidade Universitária Paulo VI, Tirirical, São Luís, MA 65050-150, Brazil. E-mail: alana@elo.com.br

The swear turtle "jurará" (Kinosternon scorpioides) is a mud turtle of the Amazon region exposed to disordering capture in the rural areas of Maranhão, Brazil. Despite its popularity in these areas, little meaningful information regarding the reproductive morphology is currently available, fact that impedes the adoption of policies for preservation of the species. To obtain more information, we studied the ovarian morphology adult jurará females kept in captivity by morphological and morphometric analysis in the dry and rainy season. The results revealed that all females were sexually mature and were in a vitellogenic period. The ovaries are two irregular structures composed by follicles in different stages of development (primary, secondary and tertiary) scattered in a stroma of loose connective highly vascularized tissue. The ovary weight was $6.25 \pm 4.23 \mathrm{~g}$ and $2.27 \pm 1.42 \mathrm{~g}$, for the right and left one respectively. The gonadosomatic indexes were $2.06 \%$ for the dry season and $1.79 \%$ for the rainy season. The average of the follicles was 29.83 units per ovary. Microscopically, the mature ovaries revealed a basal layer composed by four cellular layers: the inner and outer theca, stratum granulosum with perivitelline membrane and zona radiata with vitelline membrane. No significant differences were observed in the ovaries either in the dry or wet period.
\end{abstract}

INDEX TERMS: Ovary, turtle, Kinosternon scorpioides, Kinosternidae, reproduction, morphology.

\footnotetext{
${ }^{1}$ Received on January 14, 2011.

Accepted for publication on March 5, 2012.

${ }^{2}$ Secretaria Municipal de Agricultura, Pesca e Abastecimento (Semapa), BR 135 Km 0 s/n, Tirirical, São Luís, MA 65095-600, Brazil. E-mail: epc_vet@hotmail.com

${ }^{3}$ Doutoranda em Ciência Animal, Universidade Federal do Piauí (UFPI), Centro de Ciências Agrárias, Campus Agrícola da Socopo, Teresina, PI 64049-550, Brazil.

${ }^{4}$ Pós-Graduanda do Mestrado em Ciência Animal, UEMA, São Luís, MA.

${ }^{5}$ Departamento das Clínicas Veterinárias, Centro de Ciências Agrárias (CCA), UEMA, São Luís, MA.

${ }^{6}$ Programa de Pós-Graduação em Anatomia dos Animais Domésticos e Silvestres, Departamento de Cirurgia, Faculdade de Medicina Veterinária e Zootecnia (FMVZ), Universidade de São Paulo (USP), Av. Prof. Dr. Orlando Marques de Paiva 87, São Paulo, SP 05508-270, Brazil.

${ }^{7}$ Departamento de Patologia, CCA-UEMA, São Luís, MA.

${ }^{8}$ Departamento das Clínicas Veterinárias, CCA-UEMA, São Luís, MA. *Corresponding author: alana@elo.com.br
}

\begin{abstract}
RESUMO.- [Aspectos morfológicos dos ovários da tartaruga Kinosternon scorpioides criada em cativeiro.] O jurará (Kinosternon scorpioides) é um cágado da Região Amazônica que sofre com as capturas desordenadas nos interiores maranhenses e que apesar da sua popularidade nessas áreas, os dados relacionados à morfologia reprodutiva ainda são poucos esclarecedores, o que dificulta a adoção de medidas para preservação da espécie. Desta forma, caracterizou-se morfologicamente os ovários de fêmeas adultas de jurara oriundas de cativeiro através da análise morfológica e morfométrica em dois períodos do ano, seco e o chuvoso. Os resultados comprovaram que todas as fêmeas eram maduras sexualmente e se encontravam em período vitelogênico. Os ovários são duas estruturas irregulares constituídas por diversos folículos em desenvolvimento (primários, secundários e terciários) sobre um estroma de tecido conjuntivo frouxo ricamente vascularizado, com
\end{abstract}


média de peso do direito e esquerdo respectivamente de $6,25 \pm 4,23 \mathrm{~g}$ and $2,27 \pm 1,42 \mathrm{~g}$. Índices gonadossomáticos de $2,06 \%$ para o período seco e de 1,79\% para o chuvoso. Média de folículos observados de 29,83 unidades por ovário. Histologicamente, os ovários maduros possuíam camada basal composta por quatro camadas celulares: as tecas externa e interna, o estrato granuloso com membrana perivitelínica e a zona radiata com membrana vitelínica. Não foram observadas diferenças significativas dos ovários entre os dois períodos estudados.

TERMOS DE INDEXAÇÃO: Ovário, tartaruga, jurará, Kinosternon scorpioides, Kinosternidae, reprodução, morfologia.

\section{INTRODUCTION}

Kinosternon scorpioides (jurara) is a small chelonian of the Amazon region, found in low flooded fields of Maranhão State. In spite of the existence of protective wildlife policies, these turtles are hunted indiscriminately to be used as a culinary delicacy by the coastal population (Pereira et al. 2007).

The ovaries are female gonads with hormonal and reproductive function. In jurara they are irregular-shaped exhibiting in the surface follicles in different stages of development (Machado Junior et al. 2006). In the juvenile female aquatic turtles they are white and very small differentl from the mature female where they are large and yellowish colored (Wyneken 2001). Similar findings were described by Machado Junior et al. (2006) in adult K. scorpioides.

The ovaries of animals under reproductive activity reveal significant morphological changes throughout the year. These changes show follicles in different developmental stages such as quiescence, proliferation and maturation. In the female turtle of Chelydra serpentina serpentina, the follicles are very small from May to June; therefore, this size increases rapidly between August and September, and ovulation occurs at the end of October (White \& Murphy 1973). It was found in Chrysemys picta that the ovarian weight decreases from July to September, or after ovulation and the nesting period (Ernst 1971). Similar observations were also described by Altland (1951) in the turtle Terrapene carolina carolina.

The period of ovarian cycle varies among reptile species. In Chrysemys picta it begins in July and August after ovulation and posture (Ernst 1971), whereas in Kinosternon flavencens it just began between September and October when the follicles became larger. Accordingly, the phases of follicular regression and quiescence occur in July and August respectively (Christiansen \& Dunham 1972).

The regular changes during the reproductive cycle of the reptile are regulated by intrinsic factors (hormones) or extrinsic (food, humidity and temperature) (Fitch 1982). Rainfall and temperature are the principal environmental factors that define the scope and behavior of these species.

In the chelonian nestling occurs during the dry season and births occur in the beginning or mid-rainy season (Souza 2004). Similarly in Hydromedusa tecifera, founded in southern Brazil, the offspring takes place in summer, mainly in November and December (Fagundes \& Bager 2007).
Based on the observations in reptile species, and the need for data regarding the reproductive morphology of the scorpion mud turtle (K. scorpioides), this study investigates the ovaries of this species maintained in captivity during two distinct periods of the year (dry and rainy season) in São Luís, Maranhão. The ovarian samples will be examined through morphologic and morphometric analysis.

\section{MATERIALS AND METHODS}

The investigation was performed in São Luís, Maranhão, Brazil (Latitude: $02^{\circ} 32^{\prime}$ S-Longitude: $44^{\circ} 17^{\prime} \mathrm{W}$ ), during the period between October 2009 to March 2010 (dry and rain season). Six female Kinosternon scorpioides turtles, older than three years of age and with the average carapace length of $14.5 \pm 0.47 \mathrm{~cm}$, were used in the present study. They were obtained from scientific breeding for research on K. scorpioides of Universidade Estadual do Maranhão (IBAMA Licence no 1899339/2008). The turtles were divided into two groups of three individuals each: Group of dry season (October-December) and Group of rain season (January-March). The animals were euthanized with sodium thiopental $2.5 \%(60 \mathrm{mg} / \mathrm{kg} / \mathrm{IV})$ intravenously after anesthesia with xylazin chloride $(4 \mathrm{mg} / \mathrm{kg} / \mathrm{IM})$ and ketamin $(60 \mathrm{mg} / \mathrm{kg} / \mathrm{IM})$. The females were dissected following the standard anatomical procedures and the reproductive organs were exposed in situ. The ovaries were photographed and weighed in digital scale. The follicles (measuring more than $10 \mathrm{~mm}$ diameter) were quantified, manually measured, and classified as small $(0.1-0.5 \mathrm{~cm})$, medium $(0.6-1.0 \mathrm{~cm})$ and large (more than $1.0 \mathrm{~cm}$ ) (Ernst 1971).

Atretic follicles and follicular scars were observed. The gonadosomatic index (GSI) of each female was realized using the formula: IGS=PTg/PTc (100); PTg is the total weight of gonads and PTc is the total body weight of each female. The gonads were immersion-fixed in $4 \%$ buffered formalin for 24 hours. After fixation the samples were dehydrated in crescent alcohol $\left(70^{\circ}, 80^{\circ}, 90^{\circ} \mathrm{e}\right.$ $100^{\circ}$ ), cleared in xylol and embedded in paraffin wax. Cutting sections of $5 \mu \mathrm{m}$ were then stained with Hematoxilin-Eosin (HE) and Masson's Trichrome. The results obtained from the morphometric analyzes were supplemented by Paired T Test and Unparied Test in the Instant program with significance level of $p<0.05$. The project was submitted to the Veterinary Ethical Research Committee of UEMA with protocol number 041/2009.

\section{RESULTS AND DISCUSSION}

The female gonads examined were composed by irregular bright-yellow masses containing follicles in different developmental stages. They were suspended by the mesovarium to the roof of the coelomic cavity (Fig.1A). Similar findings were described by Wyneken (2001) in aquatic turtle and by Machado Júnior et al. (2006) in jurara.

The presence of vitelogenic follicles in development demonstrated that all female were sexually mature. This parameter was used by several authors to determine sexual maturity in reptile simultaneously with the carapace length, presence of eggs in the uterine tubes, atretic follicles or the presence of corpus luteum in the ovaries (Ernst 1971, Wyneken 2001, Castro 2006).

Topographically, the ovaries showed evidence of relationship with: the colon and rectum medially, the uterine tubes laterally, the kidneys, caudal vena cava, dorsal aorta and the roof of the celome cavity dorsally, and, ventrally to the urinary bladder. Additionally, they are related to the 


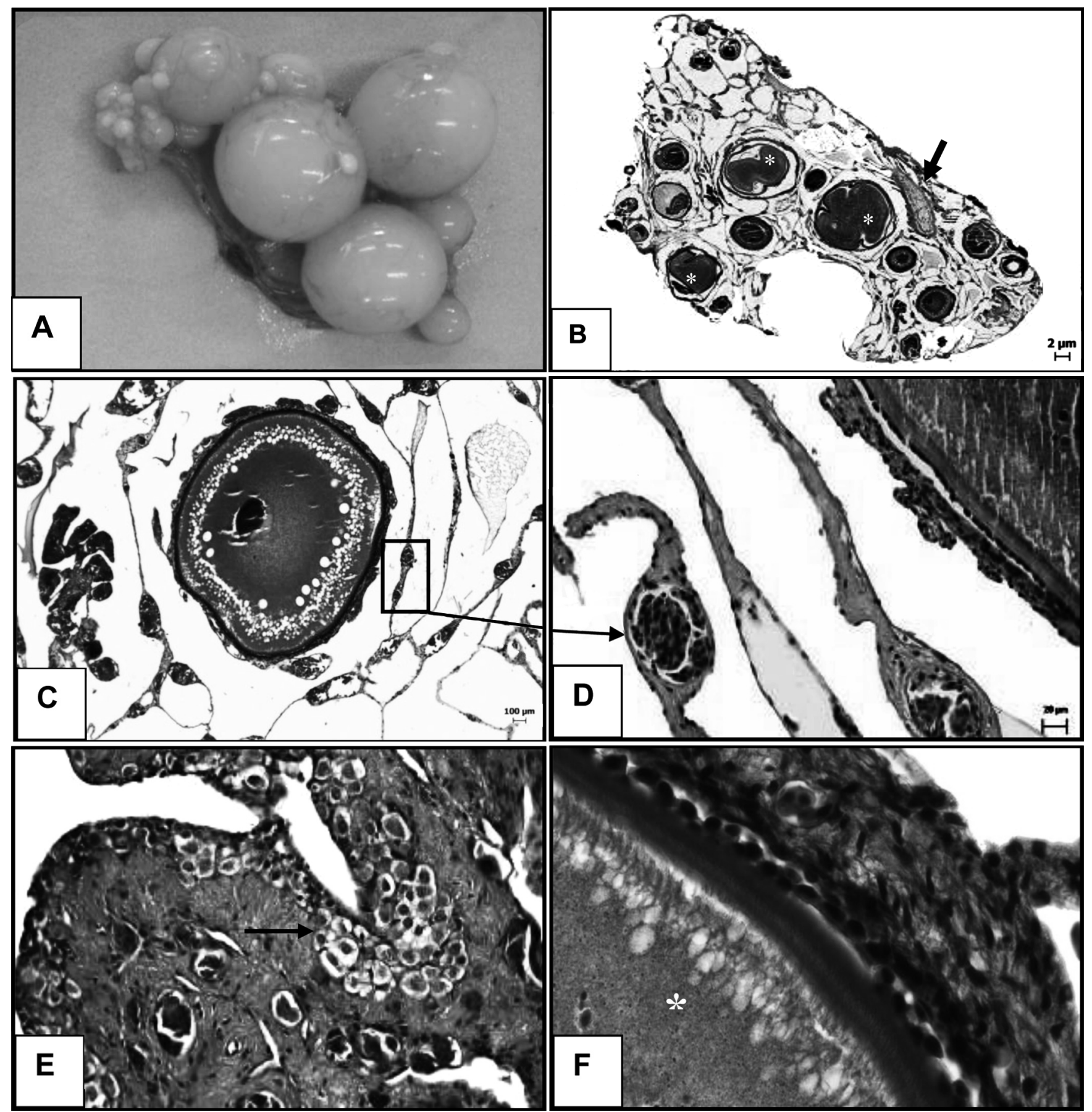

Fig.1. The Kinosternon scorpioides ovaries. (A) Right ovary with vitellogenic follicles in development. (B) Ovarian stroma containing vitellogenic follicles (asterisks) and atretic follicles (thick arrows). (C,D) Vascular network encircled the follicle in development. (E) Presence of numerous primordial follicles (thin arrow). (F) Layers of tertiary follicle-yolk (asterisk), basal membrane (blue halo), cells from the stratum granulosum (red), and layers of the theca (outer layer in blue). B,C: Masson Tricrome. D,E,F: HE (B: 4x. C: 10x. D,E,F: 40x).

lungs, small intestine, liver and stomach cranially, and to the salpinx caudally. These observations correlated well with Machado Júnior et al. (2006) findings in the same species. Therefore, the asymmetry in the ovaries size seemed to be caused by differences of the volume and quantity of follicles among the examined specimens.

The biometric data also revealed significant differences in the weight, number and size of the follicles between the right and left ovaries in the same animal. The right ovary was clearly larger and weighing more than the left. This situation probably occurred due to the major number of vitellogenic follicles developed in the right ovary comparatively to the homologue on the left. The weight was considerably different $(p=0,044)$ between the left and right ovaries, the average being $6.25 \pm 4.23 \mathrm{~g}$ and $2.27 \pm 1.42 \mathrm{~g}$, for the right and left ovaries respectively (Table 1). Altland (1951) 
reported that in the turtle Terrapene carolina carolina of the USA, similarly to the scorpion mud turtle, the weight of the right ovaries varies from October to December from 3.6 to $6.5 \mathrm{~g}$.

During this investigation, one female revealed lower weight $(1.56 \mathrm{~g})$ of the right ovary in comparison to others. This situation may possibly due to the post-ovulation period and was confirmed by the presence of two eggs in the corresponding uterine tube. Supporting this observation, Altland (1951) and Mahmoud \& Licht (1997) after their studies in turtles reported usual decrease of ovary mass in the chelonian after ovulation. During the experimental period, the average of the ovarian mass weight in the dry season $(9.13 \mathrm{~g}$ ) was slightly superior compared to $7.91 \mathrm{~g}$ of the rainy season (Table 1). This appears also to be the situation in the snake Bothrops jararaca of the south-eastern region where decrease of the ovarian mass is reportedly confined to the rainy season (October-March), period also described as ovarian recess (Janeiro-Cinquini 2004).

Among the vitellogenic follicles measuring more than $10 \mathrm{~mm}$, it was found that the quantity of this structures $(68.43 \%)$ was elevated $(p=0.0118)$ during the dry season. It seems that this is the elected period for follicular development, since ovulation occurs in the dry season (Table 2).

Regarding to the types of follicles, the small ones (87.98\%) were predominant during the dry season, whereas the quantity of medium and large follicles was variable within both periods (dry and rainy season). Moreover, the decreasing proportion in the number of small, medium and large follicles was maintained in all animals examined (Table 2). Parizzi et al. (2007) affirmed the existence of significant differences $(\mathrm{p}<0.05)$ in the number of follicles

Table 1. Quantity of vitellogenic follicles, ovarian weight, average of ovarian mass and average of gonadossomatic índex of Kinosternon scorpioides examined in dry and rainy season. São Luís-MA, 2010

\begin{tabular}{lcccccccc}
\hline \multirow{2}{*}{ Time of year } & Animals & \multicolumn{2}{c}{ FL (Qty) } & & \multicolumn{2}{c}{ PO (g) } & MO(g) & IG \\
\cline { 3 - 4 } & & $\mathrm{D}$ & $\mathrm{E}$ & & $\mathrm{D}$ & $\mathrm{E}$ & & \\
\hline \multirow{2}{*}{ Dry } & 1 & 49 & 58 & & 4.23 & 3.86 & 9.13 & 2.06 \\
& 2 & 27 & 45 & & 8.27 & 3.04 & & \\
Rainy & 3 & 36 & 30 & & 5.69 & 2.29 & & \\
& 4 & 7 & 10 & & 1.56 & 0.87 & 7.91 & 1.79 \\
& 5 & 20 & 8 & & 4.13 & 0.27 & & \\
Total & 6 & 30 & 38 & & 13.63 & 3.26 & & \\
Média & & 169 & 189 & & & & \\
Dp & & 28.17 & 31.50 & & 6.25 & 2.27 & 8.51 & 1.93 \\
& & 14.25 & 19.72 & & 4.23 & 1.42 & 5.15 & 1.17
\end{tabular}

$\overline{\mathrm{FL}}=$ ovarian follicles; $\mathrm{PO}=$ ovarian weight; $\mathrm{MO}=$ ovarian mass (average); $\mathrm{IG}$ = gonadossomatic índex (average); $\mathrm{D}=$ right ovary ; $\mathrm{E}=$ left ovary; Qty = quantity; $\mathrm{g}=$ grams, $\mathrm{Dp}$ = standard deviation.

Table 2. Classification and quantification of vitellogenic follicles of Kinosternon scorpioides in two different climatic periods. São Luís-MA, 2010

\begin{tabular}{lcccc}
\hline \multirow{2}{*}{ Time of year } & \multicolumn{3}{c}{ Type of follicle } & Total \\
\cline { 2 - 4 } & small & median & large & \\
\hline Dry & $226(62.13 \%)$ & $14(3.91 \%)$ & $5(1.39 \%)$ & $245(68.43 \%)$ \\
Rainy & $89(24.86 \%)$ & $18(5.02 \%)$ & $6(1.56 \%)$ & $113(31.56 \%)$ \\
Total & $315(87.98 \%)$ & $32(8.93 \%)$ & $11(3.07 \%)$ & $358(100 \%)$
\end{tabular}

(small, medium and large) in the ema (Rhea americana) ovaries. However, in jurara this difference was only observed between small and medium, and also, small and large follicles $(\mathrm{p}<0.01)$. No significant differences in the number of follicles were reported in both ovaries of $K$. scorpioides, even though they are invisible in major quantity in the left ovary (Table 1).

The follicular diameter revealed that the large follicles measuring more than $15 \mathrm{~mm}$ during the period of the experiment; this result is similar to the diameter of the jurara egg yolk. Thus, one could suggest that all follicles measuring $1.5 \mathrm{~cm}$ of diameter are considered pre-ovulation follicles. A similar report in the tortoise Chrysemys picta (Ernst 1971) could indicate that the follicles measured more than $15 \mathrm{~mm}$ in the same period reported in the current study.

The average of the gonadossomatic index obtained from the females in the dry season $(2.06 \%)$ was slightly superior compared to the rainy season $(1.79 \%)$, although no significant difference between the two samples was observed $(p=0.8325)$ (Table 1). In fishes, this factor has been used to determine the reproductive phase. High gonadossomatic indexes would indicate active vitellogenesis which means that the animal is under reproductive period (Querol et al. 2002). This determination was not achievable in the animals of the present study due to the absence of alterations between the two periods, fact that would indicate that the jurara went through similar reproductive phase, the vitellogenesis.

Structurally the ovaries of Kinosternon scorpioides are constituted by a reduced stroma containing follicles in different developmental stages (Fig.1B). Contrarily to the mammals where the cortical and medullar regions are easily recognizable, in the jurara, no morphological distinction could be made between those two regions in the parenchyma. The distinction between the cortical and medullar region was also reported in avian, although in this species the medullar region was diffuse and less developed (Banks 1992).

The ovarian stroma of the scorpion mud turtle (jurara) female is composed by loose connective tissue richly vascularized. The blood vessels were distributed around the borders of each follicle forming a vascular network (Fig.1C,D), different to mammals (Banks 1992) where the vascularization is only restricted to the medullar region. Smooth muscle fibers were also observed in the superficial aspect of the ovaries. Microscopically, similarly to Abas et al. (1998) descriptions, the ovaries of the scorpion mud turtle were composed by cortex and poorly defined medulla.

Positioned in the K. scorpioides ovarian stroma, primary follicles were aggregated in a region highly vascularized. It might be suggested that these follicles migrate from this region in the beginning of the follicle genesis in response to the FSH hormone (Fig.1E). Isolated primary follicles can also be observed scattered in the stroma; these follicles are composed by a single layer of epithelium enclosed by connective tissue; the secondary and tertiary follicles differ in the organization of the follicular layers, as well as in their size. Based in this statement, the tertiary follicles are larger and presented well defined follicular layers than the secon- 
dary follicles. A similar observation was made by Nasser Júnior et al. (1994) in the japanese quail (Coturnix coturnix).

It was demonstrated that the tertiary follicle wall was composed by four cellular layers from the outer surface to inside: outer theca, inner theca, stratum granulosum with perivitelline membrane and zona radiata with vitelline membrane (Fig.1F). The inner theca was composed by a layer of connective tissue sandwiched by elongated cells, whereas the cells from the outer theca were circular-shaped. This division showed similarities to that observed in the snakes Crotalus durissus and Bothrops jararaca (Almeida-Santos 2005) and ema (Rhea americana) (Parrizi 2006).

It was also noted in the present study that the theca layers of the ovaries was smooth in comparison to the ema theca layers which exhibit two thick and well defined layers. This situation appears to be related to the inferior evolutionary scale of reptiles. Atretic follicles in different development stages were also visualized in the ovarian stroma of $K$. scorpioides (Fig.1B). In these structures the connective tissue gradually occupies the follicle, and the follicular layers are disorderly arranged similarly in the japanese quail C. coturnix (Nasser Junior et al. 1994) and in the crocodile (Caiman crocodiles) (Calderón et al. 2004).

\section{CONCLUSIONS}

The ovaries of the swear turtle are structurally irregular, yellow-colored, containing follicles in different development stages scattered in a stroma of loose connective tissue highly vascularized.

The right ovary weight is always superior to the left, $6.25 \pm 4.23 \mathrm{~g}$ and $2.26 \pm 1.42 \mathrm{~g}$ for the right and left ovaries respectively. nad.

Thirty vitellogenic follicles were observed in each go-

The morphological observations within dry and rainy periods on the ovarian mass and gonadosomatic index revealed that in this year of the study climate change had little influence on the reproductive cycle of the species, and that all animals were in the vitellogenic reproductive period.

Histology revealed structural differences between the scorpion mud turtle ovaries which are structurally different from avian and mammals, particularly due to the absence of cortical and medullar region in jurara.

Acknowledgements.- To the Foundation of Research Support and Scientific Technologic Development of Maranhão (FAPEMA) for financial support, to PROCAD I Program Amazon/CAPES for technical and financial support, and to the Postgraduate Program in Animal Science, State University of Maranhão (UEMA), São Luís.

\section{REFERENCES}

Abas A.R.V., Abreu-Silva A.L. \& Pereira J.G. 1998. Estudo histológico dos órgãos do sistema reprodutor do muçuã Kinosternon scorpioides (Chelonia: Kinosternidae). Anais X Seminário de Iniciação Científica e III Encontro de Iniciação Científica, São Luís, MA. 118p.

Almeida-Santos S. 2005. Modelos reprodutivos em serpentes: estocagem de esperma e placentação em Crotalus durissus e Bothrops jararaca (Serpentes: Viperidae). Tese de Doutorado em Anatomia dos Animais Domésticos e Silvestres, Faculdade de Medicina Veterinária e Zootecnia, USP, São Paulo, SP. 204p.
Altland P.D. 1951. Observations on the structure of the reproductive organs of the box turtle. J. Morphol. 89:599-621.

Banks W.J. 1992. Histologia Veterinária Aplicada. $2^{\underline{a}}$ ed. Editora Manole, São Paulo, p.585-587.

Calderón M.L., Pérez G.R. \& Pinilla M.P.R. 2004. Morphology of the ovary of Caiman crocodilus (Crocodylia: Alligatoridae). Annals of Anatomy 186:13-24.

Castro A.B. 2006. Biologia Reprodutiva e Crescimento do Muçuã Kinosternon scorpioides (Linnaeus, 1776). Dissertação em Ciência Animal, Núcleo de Estudos em Ciência, Centro de Ciências Agrárias, Universidade Federal do Pará, Belém, PA. 100p.

Christiansen J.L. \& Dunham A.E. 1972. Reproduction of the yellow mud turtle (Kinosternon flavescens flavescens) in New Mexico. Herpetologica 28:130-137.

Ernst C.H. 1971. Sexual cycles and maturity of the turtle, Chrysemys picta. Marine Biological Laboratory 140(2):191-199.

Fagundes C.K. \& Bager A. 2007. Ecologia reprodutiva de Hydromedusa tecifera (Testudines: Chelidae) no Sul do Brasil. Biota Neotropica 7(2):179184.

Fitch H.S. 1982. Reproductive cycles in tropical reptiles. Occasional Papers of the Museum of Natural History University of Kansas, Lawrence, 96:153.

Hafez E.S.E. 2003. Reprodução Animal. 6ª ed. Editora Manole, São Paulo.

Janeiro-Cinquini T.R.F. 2004. Variação anual do sistema reprodutor de fêmeas de Bothrops jararaca (Serpente, Viperidae). Iheringia, Série Zoologia 94(3):325-328.

Machado Júnior A.A.N., Sousa A.L., Santos F.C.F. \& Pereira J.G. 2006. Morfologia dos órgãos genitais femininos do muçuã (Kinosternon scorpioides). Archs Vet. Sci. 11(2):25-29.

Mahmoud I.Y. \& Licht P. 1997. Seasonal changes in gonadal activity and the effects of stress on reproductive hormones in the common snapping turtle, Chelydra serpentina. Gen. Comp. Endocrinol. 107:359-372.

Nasser Júnior J.C., Ribeiro M.G., Teles M.E.O. \& Maruch S.M.G. 1994. Estudo morfológico do ovário da "codorninha japonesa": Coturnix coturnix (Linné, 1758) Phasianidae-Galliformes. BIOS, Cadernos do Departamento de Ciências Biológicas da PUC/MG, 2(2):13-17.

Parizzi R.C. 2006. Anatomia macroscópica e microscópica dos órgãos reprodutores femininos da Ema (Rhea amaricana). Dissertação de Mestrado em Anatomia dos Animais Domésticos e Silvestres, Departamento de Cirurgia, Faculdade de Medicina Veterinária e Zootecnia, USP, São Paulo, SP. 123p.

Parizzi R.C., Miglino M.A., Maia M.O., Souza J.A., Santos J.M., Oliveira M.F. \& Santos T.C. 2007. Morfologia do ovário da ema (Rhea americana). Pesq. Vet. Bras. 27(3):89-94.

Pereira L.A., Sousa A.L. \& Lemos J.J.S. 2007. Extrativismo de jurará Kinosternon scorpioides Linnaeus, 1766 (Reptila, Chelonia, Kinosternidae) e avaliação sócio-ambiental dos pescadores no Município de São Bento/ MA, p.269-299. In: Silva A.C. \& Fortes J.L.O. (Eds), Diversidade Biológica Uso e Conservação de Recursos Naturais no Maranhão. Vol.2. Projeto e Ações em Biologia e Química. UEMA, São Luís, MA.

Querol M.V.M., Querol E. \& Gomes N.N.A. 2002. Fator de condição gonadal, índice hepatossomático e recrutamento como indicadores do período de reprodução de Loricariichthys platymetopon (Osteichthyes, Loricariidae), Bacia do rio Uruguai médio, Sul do Brasil. Iheringia, Série Zoologia 92(3):79-84.

Souza F.L. 2004. Uma revisão sobre padrões de atividade, reprodução e alimentação de cágados brasileiros (Testudines, Chelidae). Phyllomedusa $3(1): 15-27$.

White J.B. \& Murphy G.G. 1973. The reproductive cycle and sexual dimorphism of the common snapping turtle, Chelydra serpentine serpentine. Herpentology 29(3):240-246.

Wyneken J. 2001. The anatomy of sea turtles: urogenital anatomy national. Technical Memorandum NMFS-SEFSC-470, U.S. Department of Commerce NOAA, Florida, p.153-164. 